\title{
ANALISIS KECEMASAN MATEMATIKA SISWA DALAM MENYELESAIKAN SOAL TIPE HIGHER ORDER THINKING SKILL (HOTS)
}

\author{
Dyah Ayu Safitri \\ Program Studi Pendidikan Matematika STKIP PGRI Sidoarjo, Jl. Raya \\ Kemiri, Kec. Sidoarjo, Kabupaten Sidoarjo, Jawa Timur 61234 \\ E-mail:safitridyahayu38@gmail.com \\ Intan Bigita Kusumawati \\ Program Studi Pendidikan Matematika STKIP PGRI Sidoarjo, Jl. Raya \\ Kemiri, Kec. Sidoarjo, Kabupaten Sidoarjo, Jawa Timur 61234 \\ E-mail:bigita.intan@gmail.com \\ Soffil Widadah \\ Program Studi Pendidikan Matematika STKIP PGRI Sidoarjo, Jl. Raya \\ Kemiri, Kec. Sidoarjo, Kabupaten Sidoarjo, Jawa Timur 61234 \\ E-mail:soffdah16@gmail.com
}

\begin{abstract}
Abstrak
Perasaan tegang yang hadir ketika siswa menyelesaikan masalah dalam matematika disebut dengan kecemasan matematika. Dalam kurikulum 2013 siswa dituntut untuk bisa menyelesaikan soal-soal HOTS, dalam hal ini siswa harus memiliki kesanggupan dalam mengerjakan soal-soal matematika yakni kemampuan matematika. Tujuan dari penelitian ini yakni untuk mengetahui tingkat kecemasan matematika siswa pada kemampuan matematika siswa tingkat tinggi. Jenis penelitian ini adalah penelitian deskriptif dengan menggunakan pendekatan kuantitatif. Penelitian ini dilaksanakan pada tahun ajaran 2019/2020 di SMP Negeri 1 Tanggulangin pada kelas VII 3. Subjek ditentukan dengan cara acak dilakukan dengan membagikan soal tes tipe HOTS, kemudian siswa diberi angket kecemasan matematika. Analisis data dalam penelitian ini meliputi: observasi, pengolahan data, penarikan kesimpulan kemampuan dan kecemasan matematika siswa. Hasil penelitian menunjukkan bahwa setiap tingkat kemampuan matematika siswa memiliki kecenderungan indikator kecemasan matematika yang beragam ketika menyelesaikan soal-soal tipe HOTS, yakni kemampuan matematika tinggi memiliki kecemasan matematika rendah, kemampuan matematika sedang memiliki kecemasan
\end{abstract}


matematika sedang, dan kemampuan matematika rendah memiliki kecemasan matematika tinggi.

Kata Kunci: Kemampuan Matematika, Kecemasan Matematika, Soal-soal tipe HOTS, HOTS

\begin{abstract}
Tense feelings that are present when students solve problems in mathematics are called mathematics anxiety. In the 2013 curriculum students are required to be able to solve HOTS questions, in this case students must have ability to work on mathematic problems namely mathematics ability. The purpose of this study is to determine the level of students' mathematical anxiety classified with the level of mathematical ability of students. The type of this research is a descriptive research with using a quantitative approach. This research was conducted in the 2019/2020 school year at SMP Negeri 1 Tanggulangin in class VII 3. Subjects were determined randomly by distributing HOTS type test questions, then students were given a math anxiety questionnaire. Data analysis in this research includes: observation, data processing, drawing conclusions of students' mathematical abilities and anxiety. The results of this research showed that each level of mathematical ability of students has a tendency to vary indicators of mathematics anxiety when solving HOTS type problems, namely high mathematical ability has low mathematical anxiety, moderate mathematical anxiety has moderate mathematical anxiety, and low mathematical ability has high mathematical anxiety.

Key words: Mathematics Ability, Mathematics Anxiety, HOTS Type Question, HOTS
\end{abstract}

\section{PENDAHULUAN}

Suatu permasalahan pendidikan yang terjadi di Indonesia saat ini adalah rendahnya mutu pendidikan pada setiap jenjang dan satuan pendidikan, khususnya pada pendidikan dasar dan menengah. Berdasarkan data pada Education For All (EFA) Global Monitoring Report 2011: Di Balik Krisis: Konflik Militer dan Pendidikan yang dikeluarkan Organisasi Pendidikan, Ilmu Pengetahuan, dan Kebudayaan Perserikatan Bangsa-Bangsa di New York,
Amerika Serikat menunjukkan jika indeks pembangunan pendidikan (Education Development Index) atau EDI menurut data ialah 0,934. Nilai tersebut menempatkan Indonesia berada di posisi ke-69 dari 127 negara di dunia (Anonim, 2011). Indonesia masih tertinggal dengan Brunei yang berada di peringkat ke-34 kelompok pencapaian tinggi bersama Jepang yakni berada pada posisi nomor satu di dunia. Sementara Malaysia berada pada peringkat ke-65. Posisi Indonesia jauh lebih baik dari Filiphina (85), 
kamboja (102), India (107), dan Laos (109). Hal tersebut dapat menjelaskan kualitas pendidikan di Indonesia masih tergolong rendah.

Kecemasan yang sering dialami siswa dapat disebut juga sebagai kecemasan matematika. Kecemasan terhadap matematika tidak dapat dipandang sebagai suatu hal yang biasa, karena ketidak mampuan siswa dalam mengerjakan soal matematika dapat menyebabkan siswa kesulitan terhapat matematika sehingga prestasi siswa dalam matematika menjadi rendah. Kecemasan matematika diperparah karena kondisi pembelajaran di kelas yang dirasa kurang menyenangkan.

Oleh karena itu tujuan dari penelitian ini adalah ingin mengetahui kecemasan matematika siswa pada tingkat kemampuan matematika tinggi ketika menyelesaikan soal-soal tipe HOTS yang sering dijumpai pada pembelajaran kurikulum 2013 ini.

Soal-soal dengan tipe HOTS merupakan soal-soal yang menuntut kemampuan berpikir tingkat tinggi siswa dalam proses bernalar, sehingga dapat mengasah kemampuan berpikir kritis, logis, reflektif, metakognitif, dan kreatif. Soal-soal dengan tipe HOTS dapat juga melatih siswa untuk berpikir dalam level analisis, evaluasi, dan mengkreasi. Kecemasan terdiri dari dua faktor, yaitu (Hartanti \& Dwijayanti, 2006):

Tabel 1. Faktor Kecemasan Menurut

Hartanti \& Dwijayanti (2006)

\begin{tabular}{ccl}
\hline No & $\begin{array}{c}\text { Faktor } \\
\text { Kecemasan }\end{array}$ & \multicolumn{1}{c}{ Contoh } \\
\hline 1 & Faktor Internal & $\begin{array}{l}\text { Perasaan tidak } \\
\text { mampu }\end{array}$ \\
\cline { 3 - 3 } & & $\begin{array}{l}\text { Kurang Percaya } \\
\text { diri }\end{array}$ \\
\cline { 3 - 3 } & & Perasaan bersalah \\
\cline { 3 - 3 } & & Rendah diri \\
\hline
\end{tabular}

2 Faktor eksternal Berupa penolakan

social

Kritikan dari

orang lain

Tugas yang

berlebihan

Ancaman

Kecemasan matematika dalam penelitian ini adalah reaksi emosional berupa perasaan takut, tegang, khawatir, ketika dihadapkan dengan masalah matematika. Menurut Barlow (Tisngati \& Meifinai, 2014) yaitu: 1) komponen emosional subjektif; 2) komponen kognitif; 3) reaksi psikologis; 4) tanggapan berupa perilaku. Berikut indikator angket kecemasan matematika.

Tabel 2. Indikator Kecemasan

Matematika Menurut Barlow

\begin{tabular}{|c|c|c|}
\hline No & Aspek & Indikator \\
\hline \multirow[t]{3}{*}{1.} & \multirow[t]{3}{*}{$\begin{array}{l}\text { Komponen } \\
\text { emosional } \\
\text { objektif }\end{array}$} & $\begin{array}{lcc}\text { Perasaan takut } & \text { pada } \\
\text { sesuatu yang } & \text { akan } \\
\text { terjadi } & & \\
\end{array}$ \\
\hline & & $\begin{array}{l}\text { Perasaan tegang pada } \\
\text { sesuatu yang akan } \\
\text { terjadi }\end{array}$ \\
\hline & & $\begin{array}{ll}\text { Takut/khawatir saat } \\
\text { mendapat tugas atau } \\
\text { soal-soal HOTS }\end{array}$ \\
\hline \multirow[t]{3}{*}{2.} & \multirow[t]{3}{*}{$\begin{array}{l}\text { Komponen } \\
\text { kognitif }\end{array}$} & $\begin{array}{lr}\text { Berpikir } & \text { negatife } \\
\text { terhadap } & \text { dirinya } \\
\text { sendiri } & \end{array}$ \\
\hline & & $\begin{array}{l}\text { Lupa dengan apa yang } \\
\text { telah dipelajari }\end{array}$ \\
\hline & & $\begin{array}{l}\text { Hasil belajar yang } \\
\text { tidak memuaskan }\end{array}$ \\
\hline \multirow[t]{3}{*}{3.} & \multirow[t]{3}{*}{$\begin{array}{l}\text { Reaksi } \\
\text { psikologis }\end{array}$} & $\begin{array}{l}\text { Jantung berdebar- } \\
\text { debar atau gemetar }\end{array}$ \\
\hline & & $\begin{array}{l}\text { Stres terhadap kondisi } \\
\text { tertentu }\end{array}$ \\
\hline & & $\begin{array}{l}\text { Mulas atau sering } \\
\text { buang air kecil }\end{array}$ \\
\hline \multirow[t]{2}{*}{4.} & \multirow{2}{*}{$\begin{array}{l}\text { Tanggapan } \\
\text { berupa } \\
\text { perilaku }\end{array}$} & $\begin{array}{l}\text { Menghindari situasi } \\
\text { tertentu }\end{array}$ \\
\hline & & Ingin keluar dari kelas \\
\hline
\end{tabular}


Konsentrasi mudah terganggu

\section{METODE}

Penelitian ini adalah penelitian kuantiatif deskriptif yang bertujuan untuk mengetahui kemampuan dan kecemasan matematika siswa dalam menyelesaikan soalsoal tipe HOTS. Penelitian ini dilaksanakan di SMP Negeri 1 Tanggulangin pada tahun ajaran 2019/2020 semester genap. Pengambilan sampel penelitian dilakukan secara acak (random). Kemudian diberikan soal tes kemampuan matematika dengan tipe soal HOTS serta dilakukan obsservasi yang dibantu oleh 4 rekan mahasiswa, setelah siswa diberikan soal tes kemampuan matematika selanjutnya siswa diberikan angket kecemasan matematika. Dari penelitian tersebut akan diketahui apakah siswa kelas VII mengalami tingkat

\section{HASIL DAN PEMBAHASAN}

Tingkat kemampuan matematika diketahui dengan cara memberikan soal tes kemampuan matematika yang menggunakan soal-soal tipe HOTS, kemudian didapatkan hasil tingkat kemampuan matematika siswa kelas VII 3 tergolong sedang. Untuk kecemasan dalam kategori rendah, sedang, atau tinggi pada setiap kemampuan matematika siswa.

Instrument pada penelitian ini terdiri dari soal tes kemampuan matematika yang menggunakan soal-soal tipe HOTS terdiri dari 6 pertanyaan, kemudian angket kecemasan matematika, dan observasi langsung yang dibantu oleh rekan mahasiswa.

Keabsahan data yang digunakan adalah triangulasi data dan pemeriksaan sejawat. Untuk triangulasi data dilakukan untuk menguji keabsahan data pada angket kecemasan matematika siswa, sedangkan untuk pemeriksaan sejawat digunakan pada observasi kecemasan matematika langsung ketika siswa mengerjakan soal tes kemampuan matematika menggunakan soalsoal tipe HOTS.

pengambilan data kecemasan matematika siswa menggunakan angket kecemasan matematika dan observasi secara langsung yang dilakukan oleh peneliti dan dibantu rekan-rekan mahasiswa, data kemampuan dan kecemasan matematika siswa sebagai berikut:

\section{Tabel 3. Data Siswa dengan Kemampuan Matematika Tinggi}

$\begin{array}{cccccc}\text { No. } & \text { Identitas } & \text { Nilai } & \text { Skor } & \text { Tingkat } & \text { Tingkat } \\ \text { Absen } & \text { Siswa } & \begin{array}{c}\text { Kemampuan } \\ \text { Matematika }\end{array} & \begin{array}{c}\text { Kecemasan } \\ \text { Matematika }\end{array} & \begin{array}{c}\text { Kemampuan } \\ \text { Matematika }\end{array} & \begin{array}{c}\text { Kecemasan } \\ \text { Matematika }\end{array}\end{array}$

\begin{tabular}{cccccc}
\hline $\mathbf{0 6}$ & FDW & 70 & 36 & Tinggi & Sedang \\
\hline $\mathbf{0 9}$ & ISA & 70 & 20 & Tinggi & Rendah \\
\hline $\mathbf{1 3}$ & MAA & 80 & 16 & Tinggi & Rendah \\
\hline $\mathbf{1 6}$ & MTT & 70 & 30 & Tinggi & Sedang \\
\hline $\mathbf{3 2}$ & RS & 70 & 17 & Tinggi & Rendah \\
\hline \multicolumn{2}{r}{ Rata-rata } & 72 & 24 & Tinggi & Rendah \\
\hline
\end{tabular}

Sebagai contoh peneliti mengambil sampel 3 siswa dengan kemampuan tinggi ketika menyelesaikan soal-soal tipe HOTS, pada soal nomor 1 yakni "KPK dari $9(a+b)^{2}$ dan $15(a+b)^{3}$ adalah ....” Terdapat siswa yang sudah memahami cara penyelesaian sehingga mendapatkan hasil yang tepat, tetapi ada pula 
siswa yang tidak dapat menyelesaikan dengan benar.

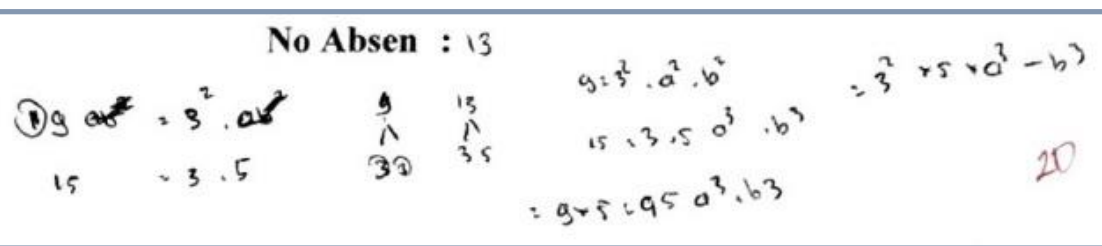

Gambar 1. Siswa pertama dapat menyelesaikan dengan tepat dan benar.

$$
\begin{aligned}
& \text { 1. kpk. } 9(a+b)^{2} \text { dan } 15(a+b)^{3}
\end{aligned}
$$

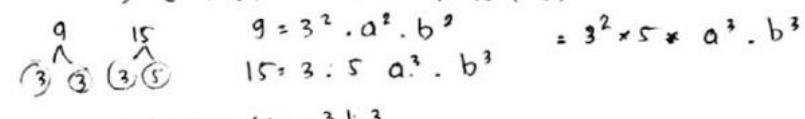

$$
\begin{aligned}
& =9 \times 5=45 a^{3} b^{3}
\end{aligned}
$$

Gambar 2. Siswa kedua dapat menyelesaikan dengan tepat dan benar.

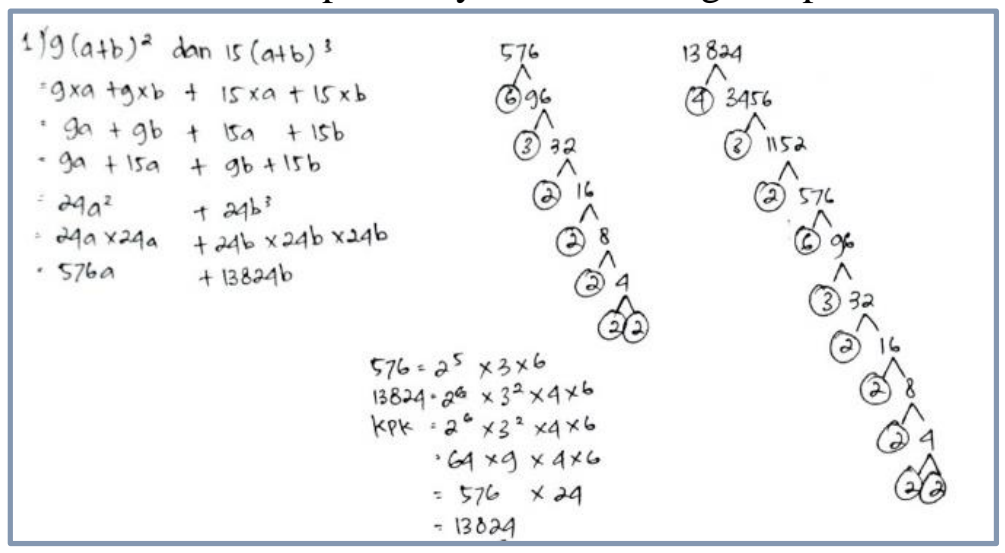

Gambar 3. Siswa ketiga tidak dapat menyelesaikan dengan benar dan tepat.

Dalam hal ini, terlihat untuk soal nomor 1 ada beberapa siswa yang dapat menyelesaikan dengan benar dan tepat tapi ada pula siswa yang tidak dapat menyelesaikan dengan tepat dan benar.

Kemudian untuk soal nomor dua yakni "Dari bentuk aljabar $R(3-2 R) \geq 0$, apakah bentuk aljabar tersebut merupakan pertidaksamaan linear satu variabel? Berikan alasannya!" Terdapat siswa yang dapat menyelsaikan dengan benar ada juga siswa yang belum bisa menyelesaikan dengan benar.

$$
\begin{aligned}
& R(3-2 R) \geq 0.3 R-2 R^{2} \geq 0 \text { = Pertidaksamaan variable } \\
& \text { karna terdapart variable yang berbeda }
\end{aligned}
$$

Gambar 4. Siswa pertama tidak bisa menyelesaikan soal tersebut dengan benar

$R(3-20)$
$38-4^{2} 20$ thale persamadan variabel karena ada variabol yang beribede

Gambar 5. Siswa kedua dapat menyelesaikan soal tersebut dengan benar 


\section{Tidak, karena terdapat tanda $(\geqslant, 0)$ yang disebut variabel.}

Gambar 6. Siswa ketiga dapat menyelesaikan soal tersebut, tapi kurang tepat

Pada soal nomor 2 ini siswa pertama belum memahami pertidaksamaan satu variabel dengan jelas, tapi untuk siswa kedua sudah memahami apa itu pertidaksamaan satu variabel, sehingga untuk siswa kedua dapat menyelesaikan soal tersebut dengan benar. Sedangkan untuk siswa ketiga, siswa kurang memahami pertidaksamaan satu variabel itu apa, siswa tersebut mengatakan "tidak" tapi alasan yang dikemukakan kurang tepat.
Untuk soal nomor tiga yakni "Diketahui diagram venn seperti dibawah ini! Tentukan minimal 3 operasi himpunan yang mungkin sehingga hasilnya adalah bagian yang diarsir!"

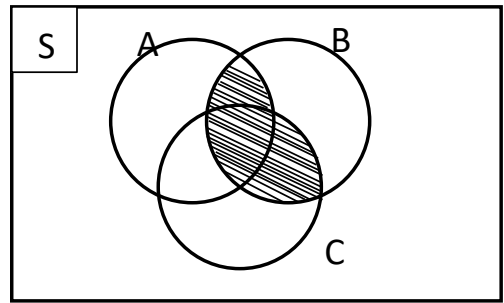

Gambar 7. Diagram Venn

Jawaban siswa pada sial ketiga ini cukup beragam seperti sebagai berikut:

$$
\begin{aligned}
& A=\{1,5,7,10,12,13\} \\
& B=\{1,3,5,7,11,13,15\} \\
& C=\{1,7,10,13,16\}
\end{aligned}
$$$$
\text { dicari } \frac{\text { asiran }}{A n b}
$$$$
\text { - } B \cap c
$$$$
\text { - An BnC }
$$

Gambar 7. Jawaban siswa pertama

$$
\begin{aligned}
& \text { Af } 1,5,7,10,12,134 \text { zican } \frac{a \text { sing }}{A n b} \\
& \text { bf } 1,7,5,2,11,13,15\}
\end{aligned}
$$

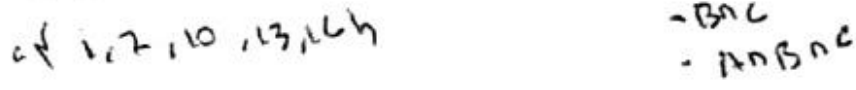

Gambar 8. Jawaban siswa kedua 


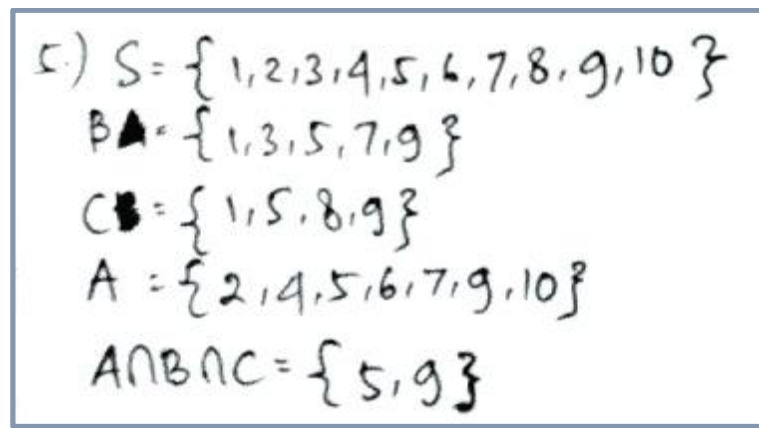

Gambar 9. Jawaban siswa ketiga

Pada soal nomor tiga ini, ketiga siswa tersebut hanya dapat membeirkan 1 atau 2 operasi himpunan yang cocok untuk diagram venn yang sudah di ketahui.

Kemudian selanjutnya diberikan angket untuk mengetahui tingkat kecemasan matematika siswa dengan kemampuan matematika tingkat tinggi sehingga diperoleh sebuah data. Dari data tersebut kemudian data angket kecemasan matematika diolah sehingga dapat menentukan untuk siswa dengan kecemasan matematika tingkat tinggi tergolong dalam kategori kecemasan matematika yang seperti apa menggunakan rumus sebagai berikut:

$R_{I}=\frac{\left(5 \times \sum S S\right)+\left(4 \times \sum S\right)+\left(3 \times \sum N\right)+\left(2 \times \sum T S\right)+\left(1 \times \sum S T S\right)}{n}$

Kemudian didapatkan data sebagai berikut:

Tabel 4. Data Angket Siswa

\begin{tabular}{|c|c|c|c|c|c|c|c|c|c|c|c|c|}
\hline \multirow{2}{*}{$\begin{array}{l}\text { Nomor } \\
\text { Absen }\end{array}$} & \multicolumn{12}{|c|}{ Indikator ke- } \\
\hline & 1 & 2 & 3 & 4 & 5 & 6 & 7 & 8 & 9 & 10 & 11 & 12 \\
\hline 06 & 3 & 4 & 4 & 3 & 1 & 4 & 3 & 2 & 2 & 4 & 2 & 4 \\
\hline 09 & 1 & 2 & 1 & 1 & 2 & 2 & 2 & 2 & 2 & 2 & 1 & 1 \\
\hline 13 & 2 & 2 & 1 & 1 & 1 & 1 & 1 & 2 & 2 & 1 & 1 & 1 \\
\hline 16 & 1 & 2 & 2 & 2 & 2 & 1 & 1 & 3 & 1 & 2 & 2 & 1 \\
\hline 32 & 2 & 1 & 1 & 2 & 2 & 1 & 1 & 1 & 1 & 1 & 1 & 3 \\
\hline $\begin{array}{l}\text { Rata- } \\
\text { rata } \\
\text { Skor }\end{array}$ & $\begin{array}{l}1, \\
80\end{array}$ & 2,20 & 1,80 & 1,80 & 1,60 & 1,80 & 1,60 & 2,00 & 1,60 & 1,60 & 1,60 & 2,00 \\
\hline
\end{tabular}

Setelah dilakukan analisis dari data angket yang diperoleh, siswa dengan kemampuan matematika tinggi cenderung dalam kategori rasa tegang ketika akan memulai mengerjakan soal-soal tipe HOTS, dan untuk siswa dengan kemampuan matematika sedang memiliki kecenderungan kecemasan matematika pada rasa takut atau khawatir saat mendapat tugas atau soal-soal tipe HOTS.

\section{PENUTUP}

Simpulan

Berdasarkan hasil dari penelitian kemampuan dan kecemasan matematika siswa dalam menyelesaikan soal-soal tipe High Order Thinking Skill (HOTS) dapat disimpulkan bahwa siswa dengan kemampuan matematika tinggi memiliki kecenderungan kecemasan matematika pada rasa tegang ketika akan memulai mengerjakan soal-soal tipe HOTS. Maka 
sangat diharapkan apabila peneliti lain ketika melakukan penelitian serupa, peneliti lebih memahami situasi siswa lebih diobservasi secara langsung ketika siswa mengerjakan soal-soal tipe HOTS, karena terkadang siswa tidak jujur dalam mengisi suatu angket. Dalam hal ini guru juga dapat memberikan latihan soal-soal tipe HOTS lebih banyak guna mengurangi tingkat kecemasan siswa ketika menyelesaikan soal-soal tipe HOTS, juga lebih menambah wawasan tentang cara penyelesaian agar dapat mengurangi kecemasan siswa, sehingga siswa akan lebih banyak latihan-latihan soal dengan tipe HOTS yang dapat mengurangi kecemasan ketika menyelesaikan soal-soal tipe HOTS.

\section{DAFTAR PUSTAKA}

Al-mighwar Muhamad,2007. Psikologi Remaja, Yogyakarta: Pustaka Pelajar

Anggaraeni,T. 2009. Hubungan antara kecemasan dalam menghadapi mata pelajaran matematika dengan prestasi akademik matematika pada remaja Fakultas Psikologi,Uneversitas Gunadarma

Arikunto, S. 2012. Dasar-Dasar Evaluasi Pendidikan Edisi 2. Jakarta: Bumi Aksara

Asikhia, Olubusayo. A. 2014. "Effects Of Cognitive Restructuring On The Reduction Of Mathematics Anxiety Among Senior Secondary School Students In Ogun State, Nigeria”. International Journal of Education and Research.Vol. 2 No. 2

Durand. 2010. Terori kecemasan. Yogyakarta: Pustaka pelajar

Ferdianto Ferry, 2014. Meningkatkan Kemampuan Pemahaman Matematis Siswa Melalui Problem Posing, Jurnal Euclid, Vol.1, No.1. Hal.48
Geyik, Seda Karakas. 2015. " The Effects Of Parent's Socio Economic Status On Mathematics Anxiety Among Social Sciences Students In Turkey". International Journal of Education and Research.Vol. 3 No. 1

Ghufron, Nur \& Risnawita, Rini. 2010. Teori-Teori Psikologi. Yogyakarta: AR-Ruzz Media

Imam Gunawan. Metode Penelitian Kualitatif: Teori \& Praktik. (Jakarta, Bumi Aksara, 2014). hal.81-82

Karim Asrul, 2011. Penerapan Metode Terbimbing Dalam Pembelajaran Matematika Untuk Meningkatkan Pemahaman Konsep Dan Kemampuan Berpikir Kritis Siswa, Edisi Khusus No.1. Hal.22

Manab Abdul, Penelitian Pendidikan Pendekatan Kualitatif. (Yogyakarta: Kalimedia, 2015). hal. 202

Riduwan. Dasar-Dasar Statistika. (Bandung, Alfabet, 2013).

S. Margono. Metodologi Penelitian Pendidikan. ( Jakarta, PT. Rineka Cipta, 2004). hlm. $38-42$

Sugiyono. Metode Penelitian Pendidikan : Pendekatan Kuantitatif, Kualitatif, dan $R \& D$. (Bandung: Alfabet, 2016).hal. 199

Sutame, Ketut \& Harpinto. 2012. "Mereduksi Mathematics Anxiety Dan Menyuburkan Problem Solving Ability Dengan Pendekatan Problem Posing”. Prosiding dalam Seminar Nasional Matematika dan Pendidikan Matematika,UNY, ISBN: 97897916353-8-7.

Tisngati, Urip \& Meifiani, Nely Indra. 2014. Studi Terhadap Pola Asuh Orang 
Tua, Kecemasan, dan Kepercayaan

Diri. Yogyakarta: Nuha Medika

Usman Fauzan Alam, Kemampuan Pemahaman Matematika Siswa Melalui Model Pembelajaran Auditory Intellectualy Repetition Dan Problem Based Learning, Jurnal Pendidikan Matematika, Vol.11, No.1, Januari 2017. Hal.71

Usman Fauzan Alam, Kemampuan Pemahaman Matematika Siswa Melalui Model Pembelajaran Auditory Intellectualy Repetition Dan Problem Based Learning, Jurnal Pendidikan Matematika, Vol.11, No.1, Januari 2017. Hal.72

Wahyudin, Analisis Kemampuan Menyelesaikan Soal Cerita Matematika Ditinjau Dari Kemampuan Verbal, Jurnal Tadris Matematika, Vol.9 No.2 November 2016. Hal.150

Wahyudin.2010. Monograf: Kecemasan Matematika. Bandung: Program Studi Pendidikan Matematika SPS UPI. 